\title{
INVESTIGATION ON THE EFFECT OF THERMAL BARRIER COATING IN A DIESEL AND MICROALGAE METHYL ESTER POWERED COMPRESSION IGNITION ENGINE
}

\author{
Nambaya Charyulu Tatikonda ${ }^{1,2,}$, P. Naveenchandran ${ }^{3}$, E. Raja ${ }^{3}$ \\ and C. Thamotharan ${ }^{3}$ \\ ${ }^{1}$ Research Scholar, Department of Mechanical Engg., BIHER, Chennai, Tamil Nadu, India \\ ${ }^{2}$ Department of Mechanical Engg., SVIST, Tiruvuru-521235, Andhra Pradesh, India \\ ${ }^{3}$ Department of Automobile Engg., BIHER, Chennai, Tamil Nadu, India \\ ${ }^{\square}$ Corresponding Author: tnchoney@gmail.com
}

\begin{abstract}
Biodiesel is the most promising and sustainable substitute for fossil diesel, it is renewable and can be derived from various plant species, seeds, and microorganisms. It can more efficiently be utilized in low heat rejection (LHR) engines. The present work was carried out to improve the performance, emission, and combustion characteristics of thermal barrier coated diesel engine running on the blends of pure diesel and microalgae methyl ester (MAME). In this study, the crown portion of the piston was coated with yttria-stabilized zirconia (YSZ) of about $350 \mu \mathrm{m}(0.35$ $\mathrm{mm}$ ) using plasma spray coating technique. During experimentation, a set of tests were conducted with various diesel and MAME blends ranging from $10 \%$ to $30 \%$ with base engine and coated engine at several load conditions. Finally, the experimental values of performance, emission, and combustion characteristics of all tested samples were analyzed and compared with those of pure diesel values with an uncoated piston. The result data revealed that a significant improvement was found for the coated engine with all the blends in terms of reduced brake specific fuel consumption, increased brake thermal efficiency, and reduced $\mathrm{CO}, \mathrm{HC}, \mathrm{NO}_{\mathrm{x}}$ emissions with increased $\mathrm{CO}_{2}$, exhaust gas temperature, and Smoke opacity. The cylinder peak pressure and maximum heat release rate were also increased with reduced ignition delay. Of all the blends, the blend B30 has exhibited far better results with the coated engine.

Keywords: LHR Diesel Engine, Yttria-Stabilized Zirconia, Plasma Spray Coating, Microalgae Methyl Ester, Performance, Emission, Combustion

RASĀYAN J. Chem., Vol. 14, No.3, 2021
\end{abstract}

\section{INTRODUCTION}

The energy from various renewable sources is a consoling choice soon since it safeguards the environment from greenhouse gas emissions. It reinvigorates the economy of the country by intensifying the demand and cost of the several agricultural products which may be used for producing biofuel and bring down the dependency on petroleum products. ${ }^{1}$ Renewable energy is a hopeful source of energy for future success to keep the environment in a safe zone. Bioenergy was anticipated to diminish the dependency on conventional fossil fuels with its connected governmental and lucrative infirmity, minimize the greenhouse emissions and other related issues to reinvigorate the financial wealth to increase the demand and prices of the agricultural outcomes. ${ }^{2}$ Microalgae Chlorella Vulgaris biodiesel plays a remarkable role in the minimization of universal environment degradation. This noble feedstock can be grown in wastewater extracted out of agricultural, municipal, and industrial day-to-day activities which potentially provides not only economical but also an environmentally friendly feedstock for producing biodiesel. ${ }^{3}$

Low heat rejection (LHR) diesel engine generally is partially similar to a standard diesel engine concerning knocking density, mass fuel burning rate, average exhaust gas temperature, coefficient of heat transfer, velocity of heat transfer and total heat transfer, ${ }^{4}$ it paves the path to reduce the heat loss to engine coolant thereby increasing combustion temperature. ${ }^{5}$ Ekrem Buyukkaya et al. have reported the effect of thermal coating with $\mathrm{MgZrO}_{3}$ and mineral diesel as a fuel with 1- 8\% reduction in brake specific fuel consumption, and $11 \%$ decrement in $\mathrm{NO}_{\mathrm{x}}$ emission, ${ }^{6}$ and almost similar results were obtained by Hanbey Hazar with canola methyl ester blends, ${ }^{7}$ M. Ciniviz et al. have communicated the results from their

Rasayan J. Chem., 14(3), 1972-1984(2021)

http://doi.org/10.31788/RJC.2021.1436325

This work is licensed under a CC BY 4.0 license. 
RASĀYAN J. Chem.

Vol. 14 | No. 3 |1972-1984| July - September | 2021

experience with coated engine operated with pure diesel, a significant decrease in BSFC (Brake Specific Fuel Consumption), Smoke emission and increase in $\mathrm{NO}_{\mathrm{x}}$ (Oxides of Nitrogen) emission, ${ }^{8}$ similar results reported by $\mathrm{M}$. Mohamedmusthafa et al. with $\mathrm{Al}_{2} \mathrm{O}_{3}$ thermal barrier and diesel and pongamia methyl ester blends. ${ }^{9}$ Huseyin Aydin disclosed the influence of $\mathrm{ZrO}_{2}$ coated engine powered with diesel and pure vegetable oil blends, that the possibility of higher thermal efficiency and improved fuel economy and lower emissions except for oxides of nitrogen, ${ }^{10}$ similar conclusions were made by M.J. Abedin et al. in their review, ${ }^{11}$ and Bahattin Iscan with his investigation on $\mathrm{ZrO}_{2}$ coated engine worked with diesel and pure cotton sed oil blends. ${ }^{12}$ Selman Aydin et al. have investigated the usefulness of biodiesel produced from residuary cotton seed frying oil in a single-cylinder diesel engine coated with a mixture of $88 \%$ $\mathrm{ZrO}_{2}, 4 \% \mathrm{MgO}$ and $8 \% \mathrm{Al}_{2} \mathrm{O}_{3}$ and found that, partial decrement in BSFC, $\mathrm{CO}$ (Carbon monoxide), $\mathrm{HC}$ (Hydrocarbon) and smoke emissions, and partial increment in power and $\mathrm{NO}_{\mathrm{x}}$, the cylinder pressure was increased with the coated engine and no increment was found in heat release rate, ${ }^{13}$ similar findings were communicated by A. Vadivel and S. Periyasamy, ${ }^{14}$ and analogous conclusion was made through coating with yttria stabilized zirconia, ${ }^{15}$ and with Titanium dioxide $\left(\mathrm{TiO}_{2}\right)$ coated engine running on pongamia methyl ester blends. ${ }^{16}$ Chiranjeeva Rao Seela et al. have analyzed zirconia thermal barrier coated twincylinder diesel engine fuelled with mineral diesel and sunflower oil methyl ester blends and outlined that at medium loads the emissions of $\mathrm{CO}$ and $\mathrm{HC}$ are minimized, ${ }^{17}$ and better emission characteristics were obtained by V. Karthickeyan et al. during their energy and exergy analysis with $20 \%$ pomegranate seed oil with YSZ (Yttria Stabilized Zirconia) coated engine. ${ }^{18} \mathrm{D}$. Das et al. have publicized the results of their investigation on a thermally barriered engine with partially stabilized zirconia (PSZ) with $\mathrm{AI}_{2} \mathrm{O}_{3}$ for bond coat, and stated an improvement in brake thermal efficiency, brake specific fuel consumption and decrement in harmful gases, particulates with increment in $\mathrm{NO}_{\mathrm{x}}$ emission, ${ }^{19}$ similar findings were delineated with fossil diesel and neem oil methyl ester blends, ${ }^{20}$ accompanied by diesel and waste cooking oil methyl ester blends, ${ }^{21}$ and as well as for waste plastic oil. ${ }^{22}$ Contradictory result was registered in terms with decreased $\mathrm{NO}_{\mathrm{x}}$ with non-edible oils, ${ }^{23}$ with diesel and orange oil methyl ester blends, ${ }^{24}$ with pumpkin seed oil methyl ester blends, ${ }^{25}$ and from cashew nut shell lipid methyl ester blends. ${ }^{26}$ Elevated brake thermal efficiency, minimized brake specific fuel consumption and declined emissions except $\mathrm{NO}_{\mathrm{x}}$ were registered with kapok oil methyl ester blends, ${ }^{27}$ with pure diesel and pure biodiesel when the engine was coated with yttria-stabilized zirconia. ${ }^{28}$ Similar results were obtained from lanthanum zirconate coated engine with rapeseed oil methyl ester blends, ${ }^{29}$ and with lemon oil blends, ${ }^{30}$ with Alumina-zirconia $\left(\mathrm{AI}_{2} \mathrm{O}_{3}-\mathrm{ZrO}_{2}\right)$ composite coated engine with diesel and punnai methyl ester blends, ${ }^{31,32}$ but decrement in $\mathrm{NO}_{\mathrm{x}}$ with Alumina coated engine fuelled by mahua biodiesel, ${ }^{33}$ an appreciable improvement in performance and emissions were identified with conventional diesel and vegetable oil blends operated in a diesel engine coated with copper and cadmium nano catalyst. ${ }^{34}$ Enhanced BTE and downturned BSFC with reduced tailpipe emissions such as $\mathrm{CO}, \mathrm{HC}$, Smoke, and increased $\mathrm{NO}_{\mathrm{x}}$ were noticed during the exploration on the engine coated with yttria-stabilized zirconia (YSZ) powered with diesel and Cymbopogon flexuous biofuel blends doped with cerium oxide nanoparticles, ${ }^{35}$ and with reduced $\mathrm{NO}_{\mathrm{x}}$ similar consequences were reported with yttria and ceria stabilized zirconia coated engine fuelled by pure diesel doped with cerium oxide nanoparticles. ${ }^{36}$

The above available literature reported various aspects of diesel engine operation with several types of thermal barrier coatings and different kinds of biodiesel, diesel blends. Almost all the researchers have produced similar results in terms of performance and combustion, but in case of tailpipe emissions a lot of contradictory was identified irrespective of the coating material and fuel used. The literature has reported dissimilar findings towards tailpipe emissions such as $\mathrm{CO}, \mathrm{HC}, \mathrm{CO}_{2}, \mathrm{NO}_{\mathrm{x}}$, Smoke, and exhaust gas temperature. In the existing literature on various thermal barrier coatings, the behavior of diesel engines operated with microalgae methyl ester and pure diesel blends was not identified, therefore it could be considered as a research gap for the present study and becomes a novelty of the current research work. Therefore, the present work explores the influence of Yttria-Stabilized Zirconia (YSZ) coated piston when the engine fuelled with mineral diesel and microalgae methyl ester (MAME) blends at various concentrations ranging from $10 \%$ to $30 \%$ (by volume). During this study, the performance, emission, and combustion characteristics were measured, analyzed, and compared with those of pure diesel and the rest of the test fuel samples with the uncoated engine. 
RASĀYAN J. Chem.

Vol. 14 | No. 3 |1972-1984| July - September | 2021

\section{Preparation of Coated Piston}

\section{EXPERIMENITAL}

In the present days, many researchers have been carrying out their exploration on various thermal barrier coatings over one or more parts of the diesel engine such as piston crown, inlet, and exhaust valves, cylinder wall, etc., with different layers of thickness to improve the performance, emission and combustion parameters by restricting the heat losses to the engine coolant. Yttria-Stabilized Zirconia, Partially-Stabilized Zirconia, Zirconium Oxide, Copper Oxide Titanium Oxide, Lanthanum Zirconate, and Aluminium Oxide, etc., are popularly being used as a thermal barrier coating material. In the current work, to prepare a piston for thermal barrier coating, firstly the piston crown was machined to the desired thickness (say $0.35 \mathrm{~mm}$ ) to avoid the change in compression ratio, secondly the removed thickness was compensated by YSZ coat through plasma spray coating technique, then the engine acts as a LHR engine, it withstands high temperature inside the engine cylinder during combustion process. The coating of piston was done at Spraymet Surface Technologies Pvt. Ltd. Bangalore. The piston crown before coating, after coating, and after experimentation were shown in Fig.-1.

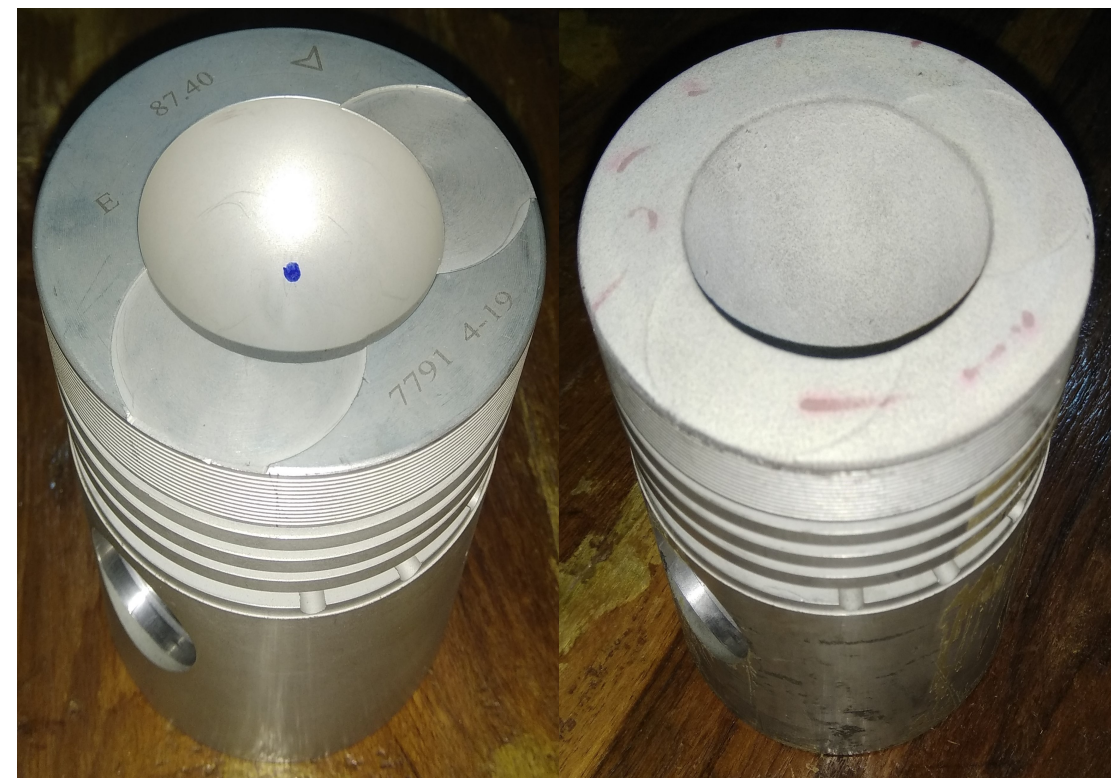

Fig.-1: (a) Piston Crown before coating

(b) Piston Crown after coating

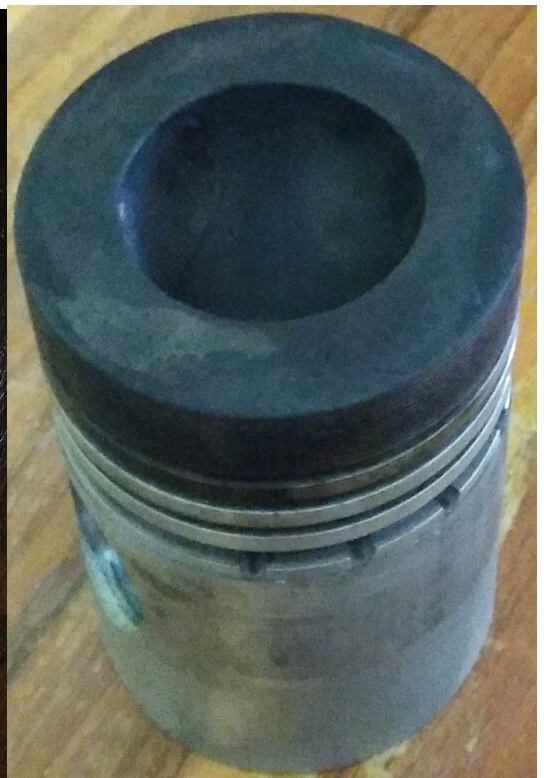

(c) After Experimentation

\section{Preparation of Biodiesel (MAME)}

Microalgae crude oil prepared from Chlorella Vulgaris was procured from biodiesel suppliers at Chidambaram, Tamil Nadu, India and it was transformed into microalgae methyl ester (MAME) using transesterification process. $250 \mathrm{ml}$ of methyl alcohol and 12 grams of potassium hydroxide as catalyst were stirred till ensuring potassium hydroxide was completely dissolved in methanol, then this solution was poured into $1000 \mathrm{ml}$ of raw microalgae oil which was already measured in a round bottom flask. Now, this mixture was subjected to continuous stirring at $720 \mathrm{rpm}$ for three to four hours at $60^{\circ} \mathrm{C}$ using a magnetic stirrer, then this hot solution was shifted to a separating funnel and allowed to cool overnight. ${ }^{1}$ Two layers are found inside the funnel, glycerine was separated and biodiesel was subjected to repeated water washings till no soap content appears, then it was heated at $100^{\circ} \mathrm{C}$ for a while to remove water particles, now it can be used as a fuel in diesel engines. Fig.-2 represents the transesterification setup, biodiesel separation while water wash, and pure microalgae methyl ester.

\section{Preparation and Properties of Test Samples}

Microalgae methyl ester and mineral diesel blends were prepared for $500 \mathrm{ml}$ quantity, firstly $50 \mathrm{ml}(10 \%)$ of microalgae methyl ester was mixed with $450 \mathrm{ml}(90 \%)$ of mineral diesel, for attaining thorough mixing it was stirred with a magnetic stirrer about 5-10 minutes, and it was tagged as MAME10D90 briefly B10, 
and the same procedure was followed to prepare another two blends $(20 \%$ and $30 \%)$ and were tagged as MAME20D80 briefly B20, and MAME30D70 briefly B30. The physicochemical properties of pure diesel, pure microalgae methyl ester, and the blends (B10, B20 \& B30) were measured experimentally at Italab Private Limited, Chennai. The properties of microalgae methyl ester were found to be approximately nearer to the property values of fossil diesel so that the microalgae methyl ester can be used as an imperishable alternative for mineral diesel. The various properties of test samples were tabulated in Table-1.

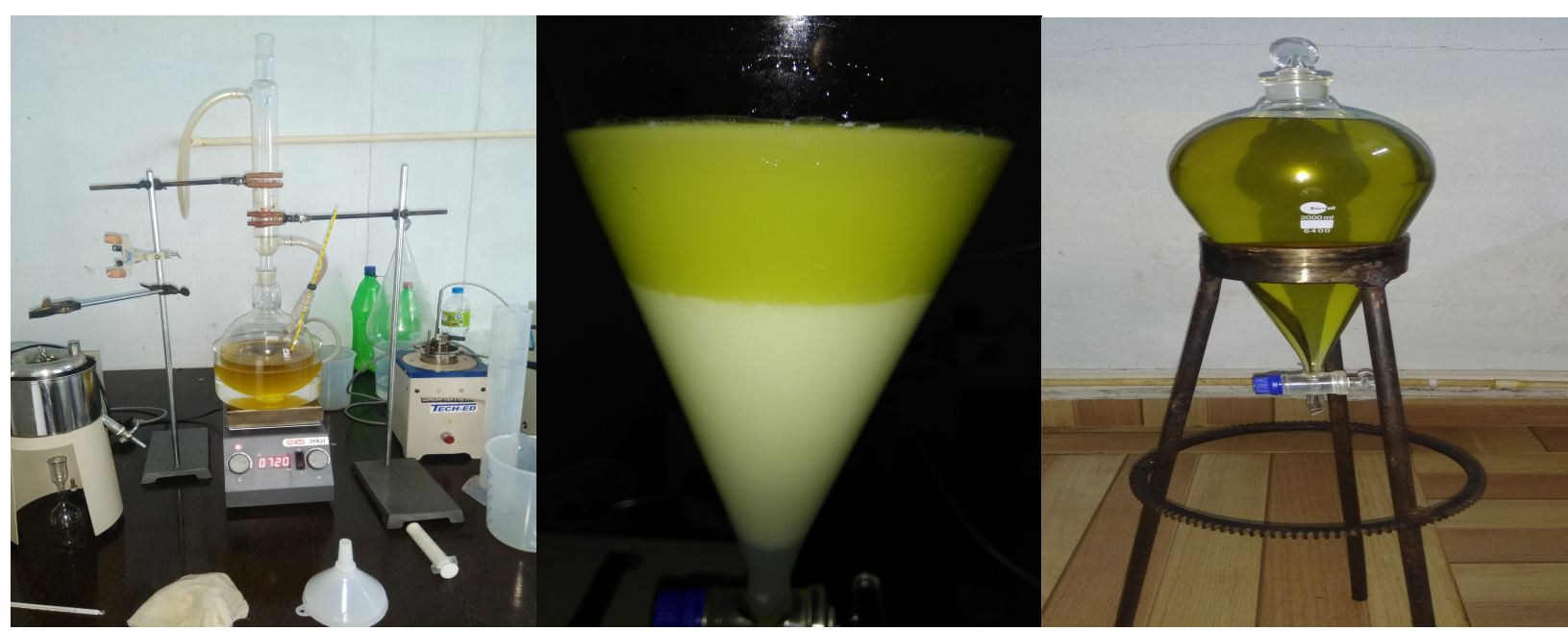

Fig.-2: (a) Transesterification Setup

(b) Biodiesel Separation

(c) Pure Microalgae methyl ester

Table-1: Physicochemical Properties of Test Samples

\begin{tabular}{c|l|c|c|c|c|c|c}
\hline S. No. & \multicolumn{1}{|c|}{ Fuel Property } & $\begin{array}{c}\text { Diesel } \\
\text { Specifications } \\
\text { ASTMD975 }\end{array}$ & $\begin{array}{c}\text { Biodiesel } \\
\text { Specifications } \\
\text { ASTMD6751 }\end{array}$ & MAME & B10 & B20 & B30 \\
\hline 1 & Density $\left(\mathrm{kg} / \mathrm{m}^{3}\right)$ & 840 & $810-900$ & 872.6 & 820.20 & 825.40 & 827.4 \\
\hline 2 & $\begin{array}{l}\text { Kinematic } \\
\text { Viscosity @ } 40^{\circ} \mathrm{C} \\
\left(\mathrm{mm}^{2} / \mathrm{S}\right)\end{array}$ & 3.8 & $1.9-6.0$ & 5.13 & 2.75 & 2.93 & 3.11 \\
\hline 3 & Flash Point $\left({ }^{0} \mathrm{C}\right)$ & 60 & $\geq 130$ & 178 & 56 & 57 & 58 \\
\hline 4 & Cetane Number & $47 \mathrm{~min}$ & $38 \mathrm{~min}$ & 46.69 & 54.64 & 54.85 & 55.06 \\
\hline 5 & $\begin{array}{l}\text { Calorific Value } \\
(\mathrm{kJ} / \mathrm{kg})\end{array}$ & 42,500 & $35,000 \mathrm{~min}$ & 38,963 & 42,551 & 41,921 & 41,291 \\
\hline
\end{tabular}

\section{Experimental Setup}

The current study was carried out on a single-cylinder four-stroke direct-injection compression ignition engine made by the Kirloskar TV1 model on which the authors have done their previous experiments ${ }^{1,2}$. This type of diesel engine is extensively being used in the field of agriculture in India. This is an eddy current dynamometer associated diesel engine. The photographic view ${ }^{2}$ of the engine setup is depicted in the Fig.-3. and the related specifications of the test engine are shown in Table-2. The needed additional equipment was attached to the engine to measure the performance and emission parameters. The various emission concentrations like $\mathrm{CO}, \mathrm{CO}_{2}, \mathrm{O}_{2}, \mathrm{UHC}$, and $\mathrm{NO}_{\mathrm{x}}$ are measured with AVL $444 \mathrm{~N}$ five gas analyzer, and smoke opacity was measured with AVL $437 \mathrm{C}$ smoke meter. Further, it is also equipped with a top dead centre encoder, a pressure sensor, and a data acquisition system along with a computer. The detailed specifications along with range and accuracy of AVL 444N five gas analyzer, and AVL 437C smoke meter were depicted in Table-3.

\section{Experimental Procedure}

The present work was carried out in three steps, firstly allowed the engine to run with pure diesel at rated speed $(1500 \mathrm{rpm})$ for a few minutes, then vary the load from zero to full load in steps $(0,25 \%, 50 \%, 75 \%$, 
and $100 \%$ ) recorded the data of performance, emission and combustion parameters at each load by using data acquisition system. Secondly, powered the engine with B10, B20, and B30 and experiment was repeated, and all the data was recorded, and thirdly, the piston of the base engine (uncoated engine) was replaced with YSZ coated piston and allowed the engine to run with the same test samples, and recorded all the necessary readings as above. In the end, experimental results of base engine and coated engine powered by fossil diesel and mineral diesel and MAME blends were analyzed and compared.

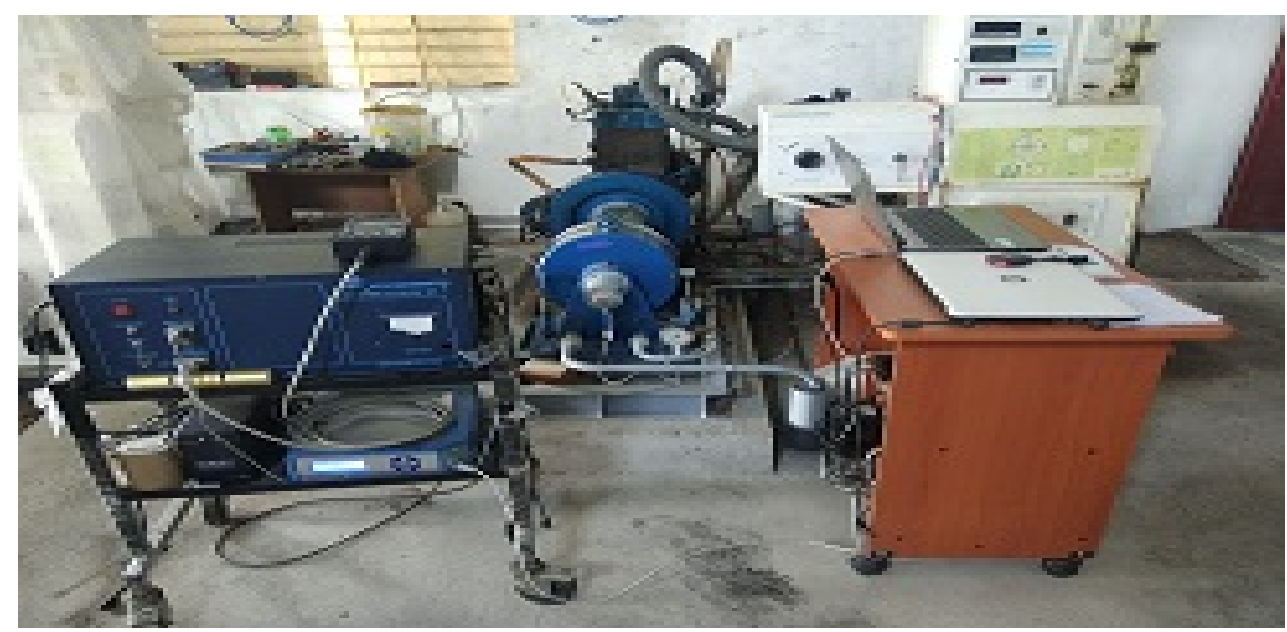

Fig.-3: Photographic View of Engine Setup ${ }^{2}$

Table-2: Specifications of the Test Rig ${ }^{1,2}$

\begin{tabular}{c|c}
\hline Make & Kirloskar \\
\hline Model & TV 1 \\
\hline Type & 1- cylinder, 4-stroke, vertical diesel engine \\
\hline Rated Power & $5.12 \mathrm{KW}$ \\
\hline Rated Speed & $1500 \mathrm{rpm}$ \\
\hline Cylinder bore & $87.5 \mathrm{~mm}$ \\
\hline Stroke Length & $110 \mathrm{~mm}$ \\
\hline Compression ratio & $17.5: 1$ \\
\hline Method of Cooling & Water cooling \\
\hline Method of Loading & Eddy current dynamometer \\
\hline
\end{tabular}

Table-3: Specifications of AVL 444N Five Gas Analyzer and AVL 437C Smoke meter ${ }^{1}$

\begin{tabular}{c|l|l|l}
\hline \multicolumn{1}{c|}{ Instrument } & \multicolumn{1}{|c|}{ Measurement } & \multicolumn{1}{c}{ Range } & \multicolumn{1}{c}{ Accuracy } \\
\hline \multirow{4}{*}{$\begin{array}{c}\text { AVL 444N Five Gas } \\
\text { Analyzer }\end{array}$} & $\mathrm{CO}$ & $0-15 \% \mathrm{Vol}$ & $+/-0.02 \% \mathrm{abs}$ \\
\cline { 2 - 4 } & $\mathrm{CO}_{2}$ & $0-20 \% \mathrm{Vol}$ & $+/-0.3 \% \mathrm{abs}$ \\
\cline { 2 - 4 } & $\mathrm{HC}$ & $0-30000 \mathrm{ppm}$ Vol & $+/-8 \mathrm{ppm}$ \\
\cline { 2 - 4 } & $\mathrm{O}_{2}$ & $0-25 \% \mathrm{Vol}$ & $+/-0.02 \% \mathrm{abs}$ \\
\cline { 2 - 4 } & $\mathrm{NO}_{\mathrm{x}}$ & $0-5000 \mathrm{ppm} \mathrm{Vol}$ & $+/-5 \mathrm{ppm}$ \\
\hline AVL 437C Smoke meter & Opacity & $0-100 \%$ & $+/-1 \%$ \\
\hline
\end{tabular}

RESULTS AND DISCUSSION

The present analysis was carried out on a single-cylinder, 4-stroke compression ignition engine without thermal barrier coated piston (Base Engine-BE), and with thermal barrier coated piston (Coated Engine$\mathrm{CE}$ ) using pure diesel and diesel and microalgae methyl ester blends in the concentrations ranging from $10 \%-30 \%$ at varying load conditions. The performance characteristics such as brake specific fuel consumption (BSFC), and brake thermal efficiency (BTE), the emission characteristics such as exhaust 
RASĀYAN J. Chem.

Vol. 14 | No. 3 |1972-1984| July - September | 2021

gas temperature (EGT), carbon monoxide (CO), carbon dioxide $\left(\mathrm{CO}_{2}\right)$, hydrocarbon $(\mathrm{HC})$, oxides of nitrogen $\left(\mathrm{NO}_{\mathrm{x}}\right)$, and smoke opacity, and combustion features like ignition delay, in-cylinder pressure, and heat release rate were measured, analyzed and compared between base engine and coated engine data.

\section{Effect on Performance Characteristics}

Figure-4 shows the variation of brake specific fuel consumption with respect to brake power for all the tested fuels with and without coated engine from zero to full load conditions. The BSFC for mineral diesel and microalgae methyl ester blends B10, B20, and B30 with the base engine at full load are 0.255 , $0.249,0.239$, and $0.239 \mathrm{~kg} / \mathrm{kWh}$ respectively, and for the coated engine with biodiesel blends are 0.236 , 0.232 , and $0.230 \mathrm{~kg} / \mathrm{kWh}$ respectively. From the experimental data, it was noticed that the BSFC has been reduced with an increase in brake power for the test samples, this was due to the fact that at higher loads engine requires less fuel because of increased in-cylinder temperature. The BSFC values for diesel and biodiesel blends with the base engine were lower than that of pure diesel and they were further lowered with the coated engine. This was due to the increased in-cylinder temperature as a result of insulated piston. ${ }^{4-36}$ It can be seen from the figure that of all the tested samples B30 with the coated engine has registered a minimum $\mathrm{BSFC}$, it was reduced by $9.8 \%$ compared to pure diesel and by $3.77 \%$ compared to B30 operated with the base engine.

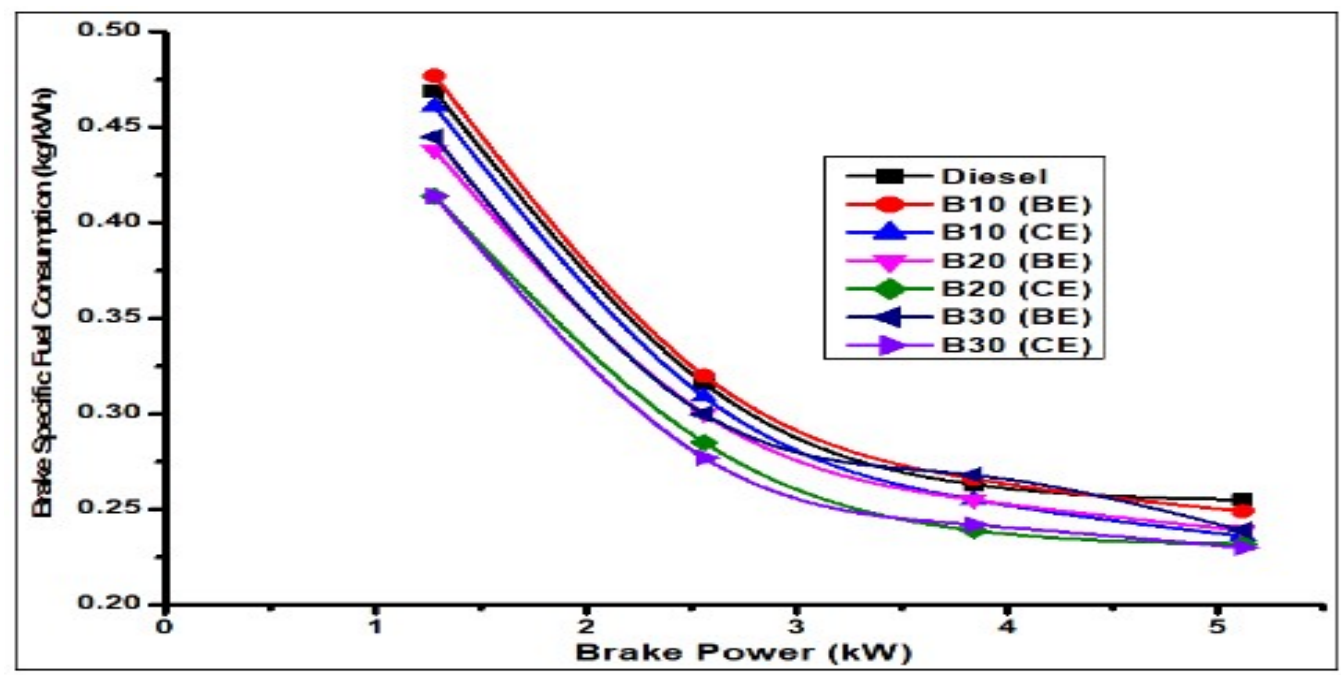

Fig.-4: Variation of BSFC (kg/kWh) with BP (kW)

Figure-5 shows the variation of brake thermal efficiency with brake power for mineral diesel and diesel and MAME blends with base and coated engine under variable loads. At full load condition, the BTE for diesel and MAME blends B10, B20, and B30 with the base engine are 33.40, 33.91, 36.10, and 36.36\% respectively, and the same for the coated engine with biodiesel blends are 35.87, 37.01, and 37.92\% respectively. It was observed from the above values that, the BTE was improved as the load increases for all the fuels with and without coated piston, and also noticed that BTE of diesel and biodiesel blends with coated engine have reached their higher values than those of pure diesel, and diesel and biodiesel blends in base engine. The higher BTE in the case of a coated engine was due to higher temperature inside the combustion chamber resulted in better vapourization of biodiesel which leads to complete combustion of fuel. ${ }^{16}$ By the comparison, it was reported that BTE of B30 with the coated engine was increased by $13.53 \%$ than pure diesel and $4.29 \%$ than $\mathrm{B} 30$ operated with the base engine.

\section{Effect on Emission Characteristics}

Figure-6 shows the variation of exhaust gas temperature along with brake power for all test samples operated in the base engine and coated engine with varying loads from 0 to $100 \%$. The measured values of EGT for fossil diesel and pure diesel and MAME blends B10, B20 and B30 powered in the base engine at full load are $377.26,336.15,333.35$, and $328.99^{\circ} \mathrm{C}$ respectively, and for biodiesel blends fuelled in the 
RASĀYAN J. Chem.

Vol. 14 | No. 3 |1972-1984| July - September | 2021

coated engine are $378.91,383.11$, and $377.80^{\circ} \mathrm{C}$ respectively. It was cleared through the figure that the EGT of diesel and MAME blends with the coated engine has been increased compared to pure diesel and diesel and biodiesel blends with the base engine. The increment in EGT for B10, B20, and B30 with the coated engine was due to thermal barrier coating which reduced the heat loss to the cooling system of the engine thereby increasing the temperature of exhaust gases. ${ }^{16,33}$ Of all the tested fuels the EGT of B30 with the coated engine was merely increased compared to pure diesel and significantly increased by $48.81{ }^{\circ} \mathrm{C}$ compared to $\mathrm{B} 30$ with the base engine though there was a significant improvement in BSFC and BTE. G. Siva Kumar and S. Senthil Kumar ${ }^{37}$ have claimed similar results.

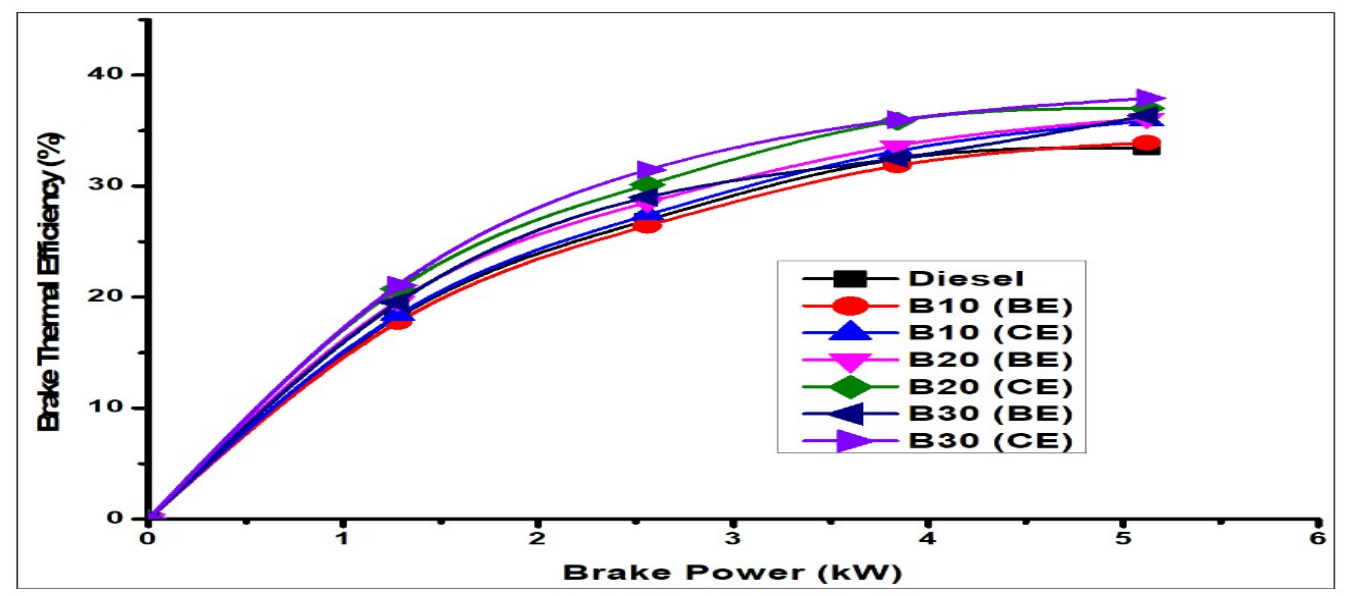

Fig.-5: Variation of BTE (\%) with BP $(\mathrm{kW})$

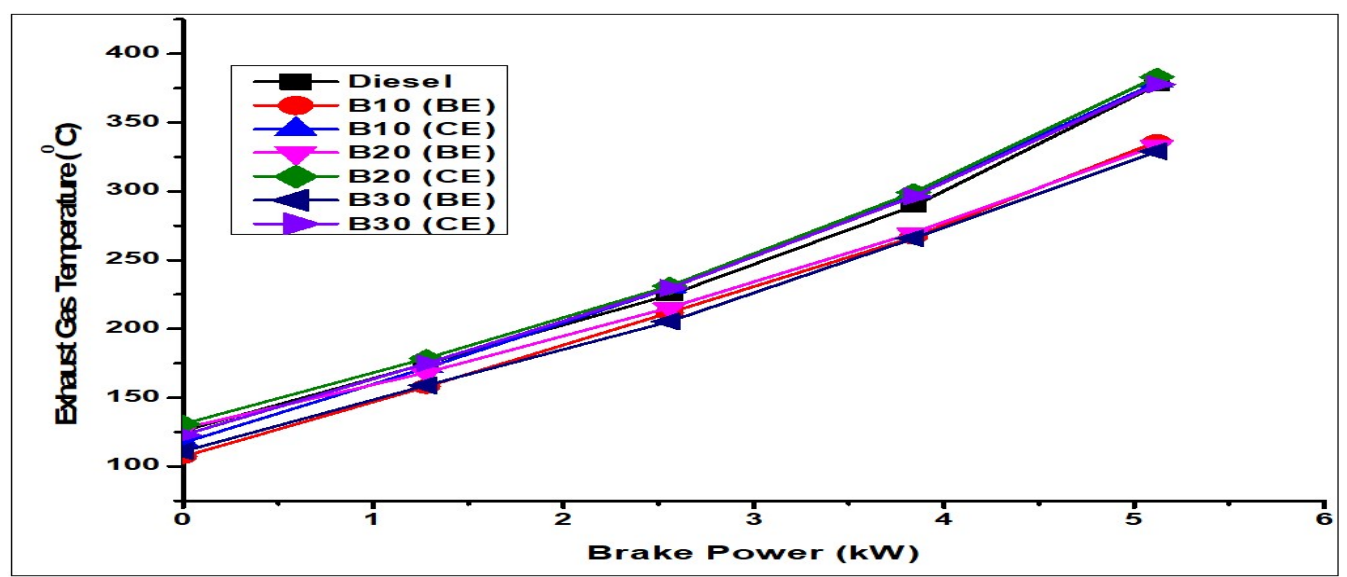

Fig.-6: Variation of EGT $\left({ }^{0} \mathrm{C}\right)$ with BP $(\mathrm{kW})$

Figure-7 shows the variation of carbon monoxide emission with an increase in brake power for mineral diesel and diesel and biodiesel blends B10, B20, and B30 with and without coated piston examined under increasing loads from zero to full load. The CO emission for all the tested fuels namely pure diesel, B10, $\mathrm{B} 20$, and $\mathrm{B} 30$ with the base engine at full load condition are, $0.239,0.126,0.088$, and $0.067 \%$ respectively, and for $\mathrm{B} 10, \mathrm{~B} 20$, and $\mathrm{B} 30$ with the coated engine are $0.113,0.072$, and $0.049 \%$ respectively. The percentage of $\mathrm{CO}$ emission represents the quality of the combustion process. Many factors such as combustion temperature, combustion pressure, air-fuel ratio, and oxygen content in the fuel influence the formation of $\mathrm{CO}$ emission. ${ }^{23}$ It can be explored from the figure that, the percentage of $\mathrm{CO}$ emission for $\mathrm{B} 30$ with the coated engine was registered $0.049 \%$, it was greatly reduced by $79.50 \%$ compared to pure diesel, and by $26.87 \%$ compared to B30 fuelled in base engine. An appreciable decrement in $\mathrm{CO}$ emission in the coated engine was caused by the complete combustion of fuel due to higher in-cylinder temperature, rich oxygen content in biodiesel, and reduced ignition delay. ${ }^{16,23,24}$

Figure- 8 shows the variation of carbon dioxide emission concerning brake power for all the test samples fuelled in the base engine and coated engine and experimented at various loads. The increased percentage 
of $\mathrm{CO}_{2}$ represents close to complete combustion. The $\mathrm{CO}_{2}$ emission at full load for conventional diesel and MAME blends B10, B20, and B30 with the base engine are 9.96, 10, 9.82, and $9.69 \%$ respectively, and for the MAME blends, B10, B20, and B30 with the coated engine are 10.5, 10.3 and 10.5\% respectively. It was observed that the carbon dioxide emission goes on increasing with an increase in brake power for all the test samples. From figure it can be noticed that the blend B30 with the coated engine has been accompanied by higher $\mathrm{CO}_{2}$ emissions than other tested fuels. This was occurred for the reason that, higher combustion temperature can be attained in a coated engine with minimized heat transfer to the combustion chamber wall and also since the biodiesel holds more oxygen content than conventional diesel. ${ }^{16,24}$ It can be inferred that the $\mathrm{CO}_{2}$ emission for $\mathrm{B} 30$ with the coated engine was increased by $5.42 \%$ compared to pure diesel and by $8.36 \%$ compared to B30 with the base engine.

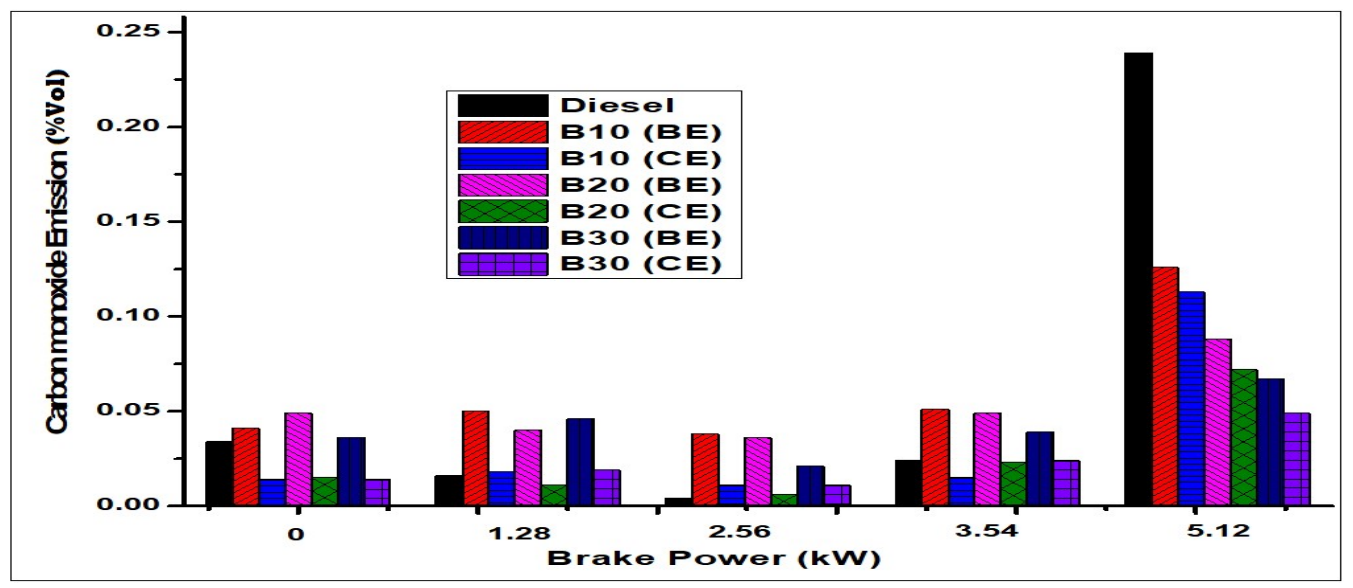

Fig.-7: Variation of CO Emission (\% by Vol) with BP (kW)

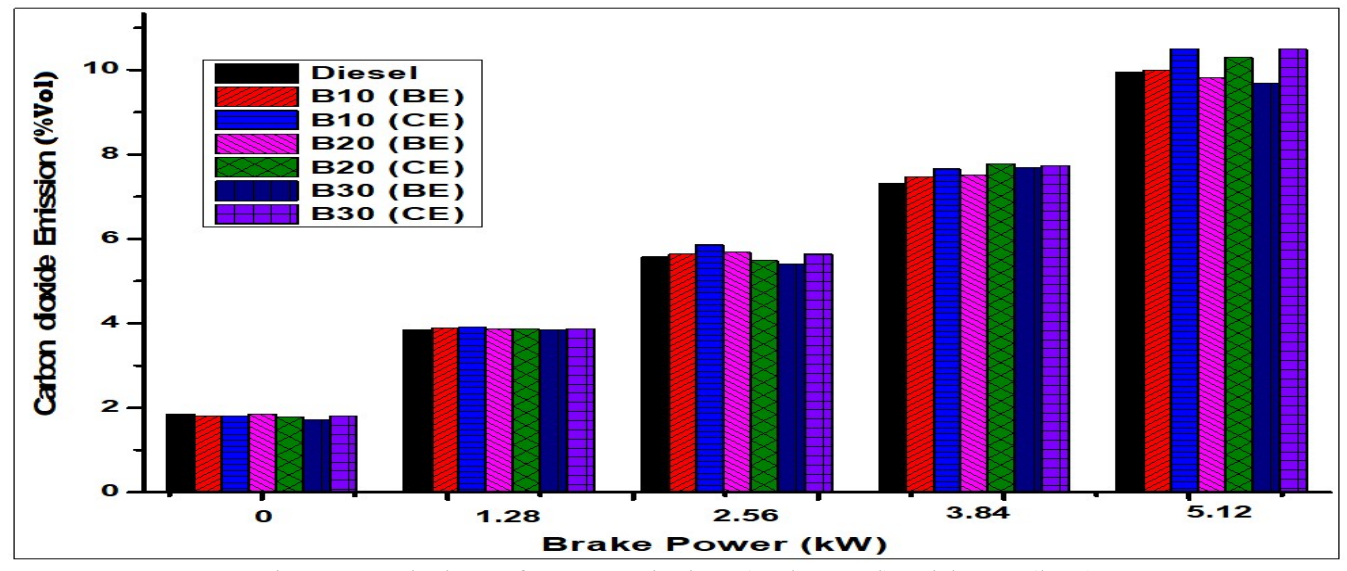

Fig.-8: Variation of $\mathrm{CO}_{2}$ Emission (\% by Vol) with $\mathrm{BP}(\mathrm{kW})$

Figure-9 shows the variation of hydrocarbon emission for brake power for all the tested fuels with and without coated piston from $0-100 \%$ load conditions. The hydrocarbon emission formation depends upon incomplete combustion and flame quenching, also the fuel properties like cetane number play an important role because the higher cetane number helps in reducing ignition delay. ${ }^{23}$ The $\mathrm{HC}$ emission at full load for mineral diesel, and blends of pure diesel and MAME B10, B20 and B30 with the base engine are 45, 54, 47 and $38 \mathrm{ppm}$ respectively, and for biodiesel blends with the coated engine are, 51, 42 and 32 ppm respectively. It could be estimated by the measurements that, the $\mathrm{HC}$ emission was gradually decreased with increasing brake power, and among all the tested samples B30 was reported with a lower value in the base engine as well as in coated engine too comparatively with pure diesel in base engine. It was resolved that the $\mathrm{HC}$ emission for $\mathrm{B} 30$ with the coated engine was reduced by $28.89 \%$ compared to pure diesel and by $15.78 \%$ compared to B30 with the base engine. The decrement in HC emission for the coated engine may be for reduced quenching distance caused by increased in-cylinder temperature which promotes complete combustion. ${ }^{16}$ 
Figure-10 shows the variation of oxides of nitrogen emission with respect to brake power for the test fuels which were under investigation with and without coated piston engine operation from zero load to full load conditions. The formation of $\mathrm{NO}_{\mathrm{x}}$ is high temperature and residual time-dependent. The $\mathrm{NO}_{\mathrm{x}}$ formation tendency increases with increased temperature inside the cylinder and fuel oxygen concentration. Generally, in biodiesel-powered coated engine operation there was more possibility for higher $\mathrm{NO}_{\mathrm{x}}$ formation than base engine operation. Most of the available research has reported higher $\mathrm{NO}_{\mathrm{x}}$ emission but very few have claimed with reduced $\mathrm{NO}_{\mathrm{x}}$ emission. ${ }^{26}$ The $\mathrm{NO}_{\mathrm{x}}$ emission for pure diesel and diesel and microalgae methyl ester blends B10, B20, and B30 with the base engine at full load are 2023, 2252, 2286, and $2288 \mathrm{ppm}$ respectively, and for biodiesel blends with the coated engine are 1732, 1680, and $1666 \mathrm{ppm}$ respectively. It was evident that the $\mathrm{NO}_{\mathrm{x}}$ of biodiesel blends was reduced in coated engine comparing with those of pure diesel and MAME blends in base engine. Of all the fuels, the blend B30 in the base engine shown higher $\mathrm{NO}_{\mathrm{x}}$ while the coated engine has shown the least $\mathrm{NO}_{\mathrm{x}}$ formation. $\mathrm{The}_{\mathrm{NO}}$ emission of $\mathrm{B} 30$ in the coated engine was reduced by $17.65 \%$ comparing to pure diesel and by $27.19 \%$ compared to $\mathrm{B} 30$ with the base engine. The decreased $\mathrm{NO}_{\mathrm{x}}$ in the coated engine may be due to the presence of higher oxygen content in biodiesel and suitable temperature conditions in the combustion chamber. ${ }^{23,24}$ Ekrem Buyakkaya and Muhammet Cerit ${ }^{38}$ have reported reduced $\mathrm{NO}_{\mathrm{x}}$ in their investigation at different injection timings.

Figure-11 shows the variation of smoke emission along with brake power for fossil diesel and biodiesel blends B10, B20, and B30 in uncoated engine and coated engine under variable load conditions. Smoke emission is mainly governed by the soot formation inside the combustion chamber. ${ }^{24}$ It was a general thought that the coated engine would produce reduced smoke opacity due to higher temperatures at the walls of the combustion chamber and gases,${ }^{16}$ and many research studies confide a decrease in smoke opacity, but the authors have found lower smoke concentration in a lower blend, and it was increased as the blend percentage increases. Smoke opacity for pure diesel and microalgae methyl ester blends B10, B20, and B30 with the base engine at full load are 61.8, 73.8, 65.3, and 55.4\% respectively, and for biodiesel blends with the coated engine are $69.8,66.8$, and $65.7 \%$ respectively. It was clear from the figure that the smoke opacity of B10 with the coated engine was reduced by $5.42 \%$ compared to B 30 , and it was still increased by $12.94 \%$ compared to pure diesel with base engine operation.

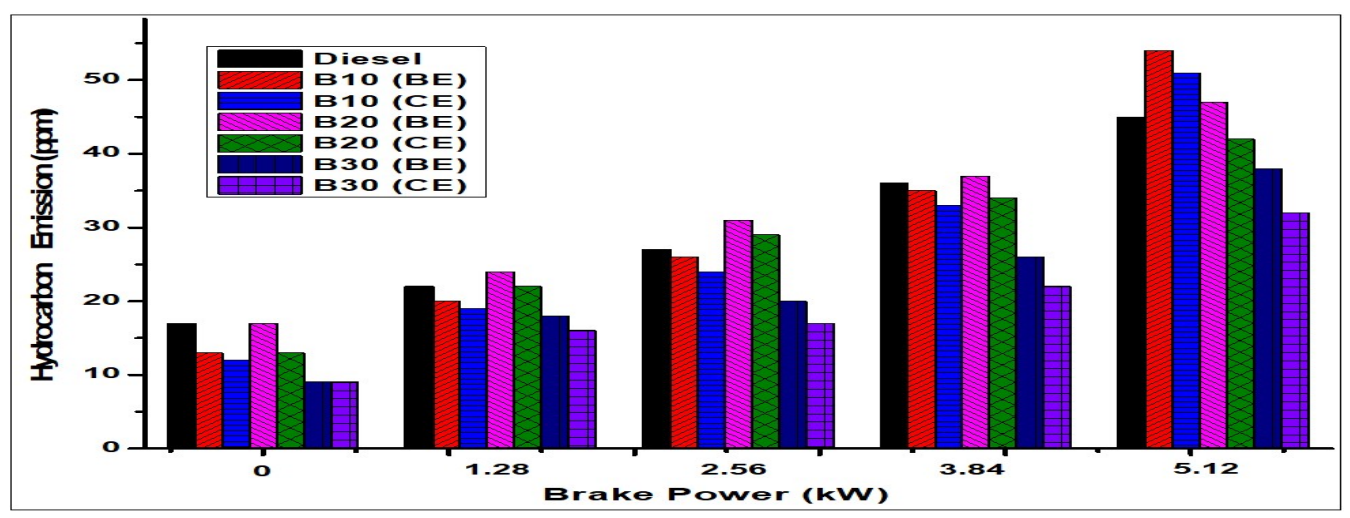

Fig.-9: Variation of Hydrocarbon Emission (ppm) with BP (kW)

Figure-12 shows the variation in ignition delay with respect to brake power of both uncoated and coated engines with all tested fuel samples at various load conditions. The ignition delay was measured in terms of crank angle difference between the start of injection and the start of combustion of fuel. The ignition delay for base engine fuelled with pure diesel and MAME blends B10, B20, and B30 at full load are 11, $10,09,09^{\circ} \mathrm{CA}$ respectively and for coated engine operated with $\mathrm{B} 10, \mathrm{~B} 20$, and $\mathrm{B} 30$ are 08,07 , and $07^{\circ} \mathrm{CA}$ respectively. It was revealed from the figure that the ignition delay of the coated engine with $\mathrm{B} 30$ was reduced by $4^{0} \mathrm{CA}$ compared to the operation with pure diesel and by $2^{\circ} \mathrm{CA}$ compared to the operation with $\mathrm{B} 30$ in the base engine. The reduced ignition delay may be resulted from the attainment of the higher temperature inside the combustion chamber which speeds up the combustion process in coated engines compared to base engine operation. M. Prabhahar and K. Rajan ${ }^{16}$ have reported a similar result. 
RASĀYAN J. Chem.

Vol. 14 | No. 3 |1972-1984| July - September | 2021

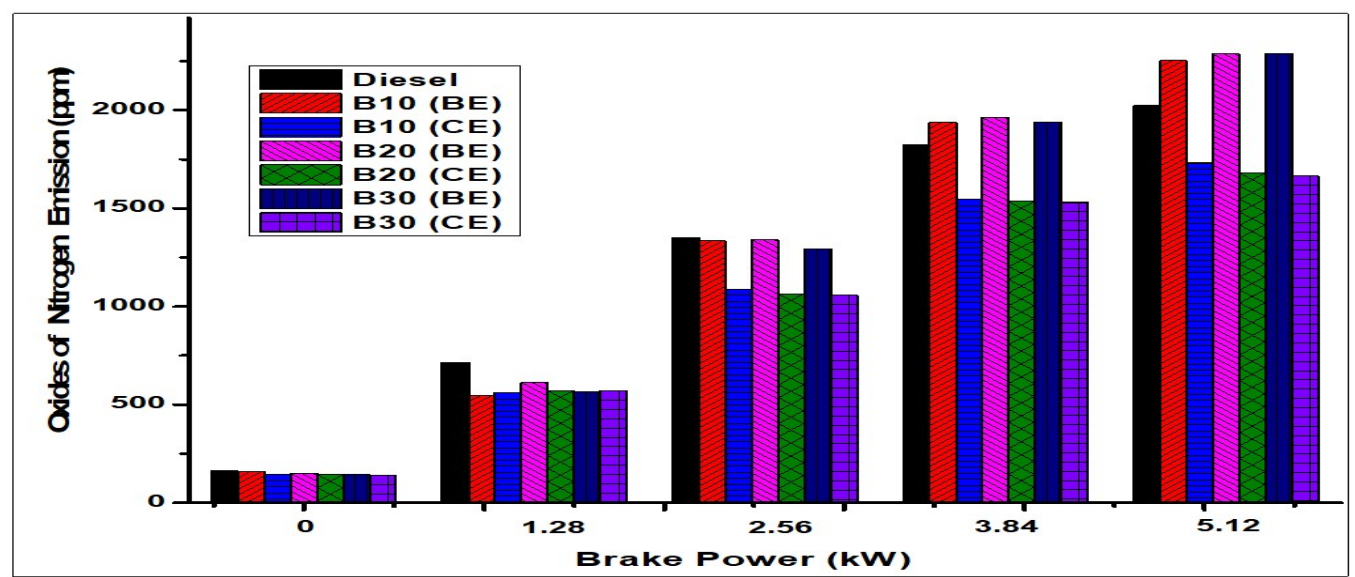

Fig.-10: Variation of Oxides of Nitrogen Emission (ppm) with BP (kW)

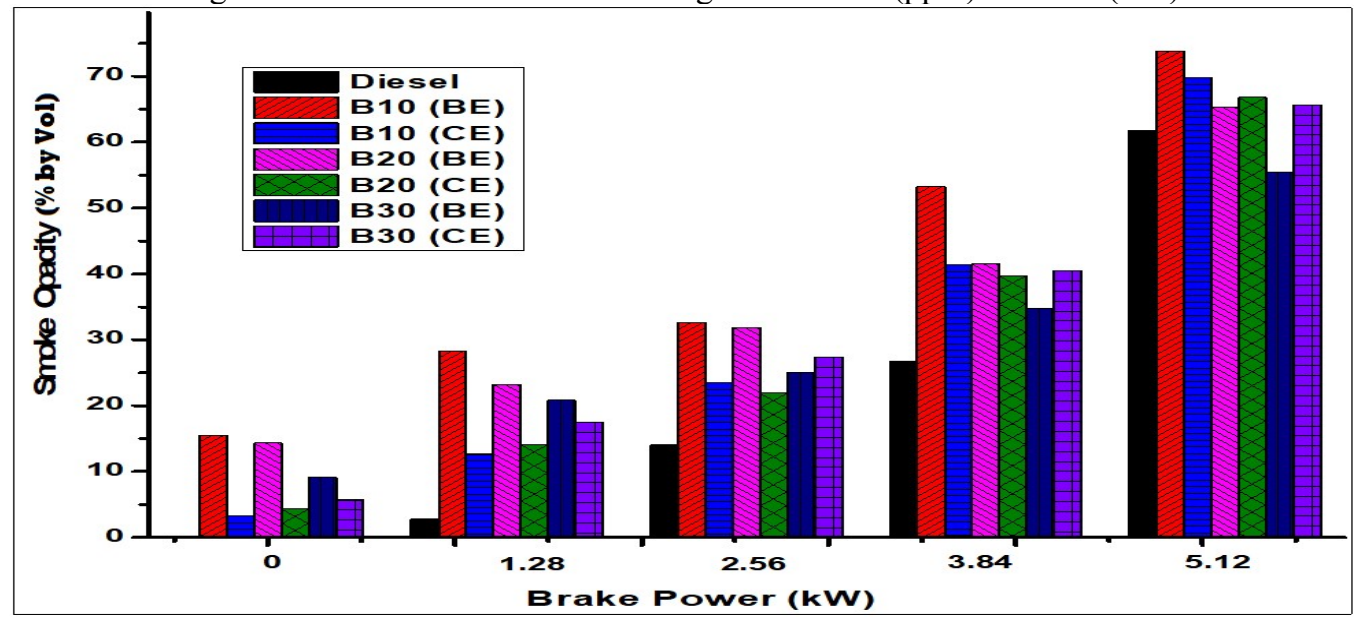

Fig.-11: Variation of Smoke Opacity (\% by Vol) with BP $(\mathrm{kW})$

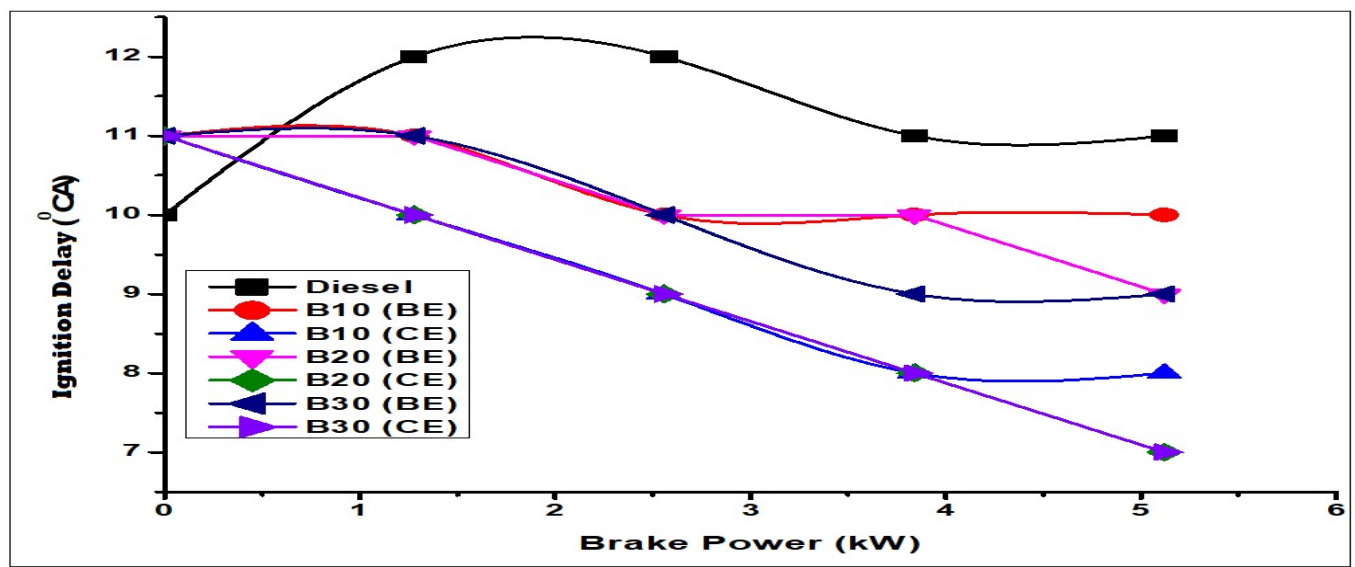

Fig.-12: Variation of Ignition Delay $\left({ }^{0} \mathrm{CA}\right)$ with $\mathrm{BP}(\mathrm{kW})$

\section{Effect on Combustion Characteristics}

Figure-13 shows the variation of in-cylinder pressure with respect to the crank angle of the base engine and coated engine for all the tested fuel samples at maximum load. The cylinder peak pressure generally depends on the amount of fuel involved in the uncontrolled combustion zone, which in turn relays on the delay period, and spray envelop of the injected fuel. ${ }^{16}$ At full load, the peak in-cylinder pressure for the base engine powered by mineral diesel and MAME blends B10, B20, and B30 are 71.77, 73.49, 73.96, and 73.68 bar respectively, and for the coated engine with biodiesel blends are 75.46, 75.49, and 75.40 bar respectively. It was identified that the cylinder peak pressure has occurred between $5^{0}$ to $8^{0} \mathrm{CA}$ after TDC (Top Dead Centre), and it can also be observed from the figure that the peak pressure for the thermal 
barrier coated engine with B20 was increased by 3.72 bar compared to pure diesel and by 1.53 bar compared to B20 in base engine operation. This is because of better combustion resulted from the higher temperature in the combustion chamber provided by the thermal barrier coating. ${ }^{16}$

Figure-14 shows the variation of the heat release rate along with the crank angle of the base engine and coated engine for all the tested fuel samples at peak load condition. The decreased ignition delay causes an increased heat release rate. ${ }^{16}$ At full load, the maximum heat release rate for the base engine fuelled with pure diesel and microalgae methyl ester blends B10, B20, and B30 are 42.07, 39.40, 39.57, and $38.03 \mathrm{~J} /{ }^{\circ} \mathrm{CA}$ respectively, and for the coated engine fuelled with $\mathrm{B} 10, \mathrm{~B} 20$, and $\mathrm{B} 30$ are $40.32,41.69$, and $42.93 \mathrm{~J} /{ }^{0} \mathrm{CA}$ respectively.

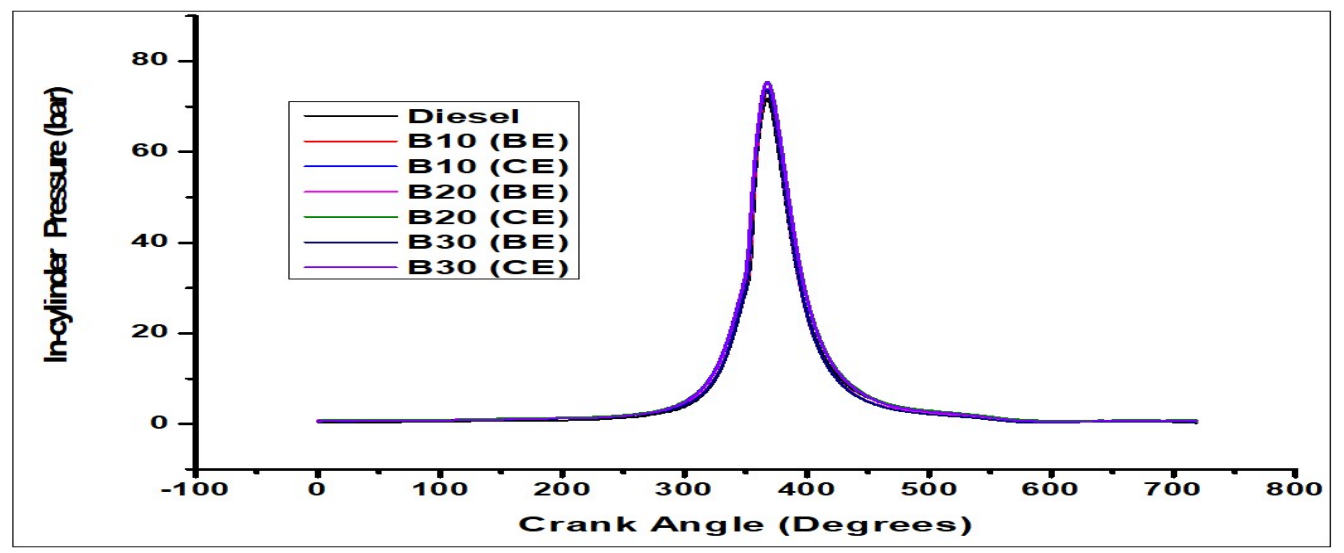

Fig.-13: Variation of In-Cylinder Pressure (bar) with Crank Angle (Degrees)

It was viewed from the figure; the maximum heat release rate has occurred between $0^{0}$ to $5^{0} \mathrm{CA}$ before TDC. It can be stated on the basis of the data that the heat release rate is higher in the coated engine with diesel and MAME blends than the base engine operation with pure diesel, and biodiesel blends. This may be due to the higher combustion temperature produced by the coated engine. B. Rajendra Prasath et al. ${ }^{39}$ have made a similar conclusion during their investigation.

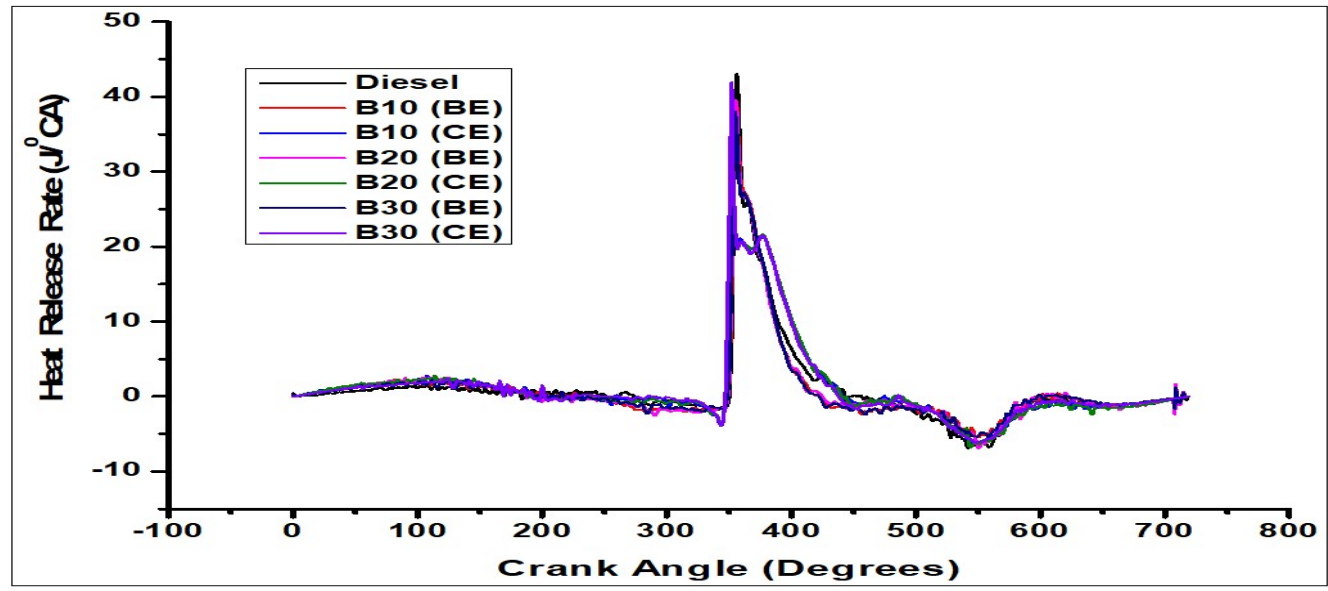

Fig.-14: Variation of Heat Release Rate $\left(\mathrm{J} /{ }^{\circ} \mathrm{CA}\right)$ with Crank Angle (Degrees)

CONCLUSION

The conclusion was made based on the above discussion that compared the characteristics of yttriastabilized zirconia coated single-cylinder diesel engine fuelled with the blends of pure diesel and microalgae methyl ester (B10, B20, \& B30) with the characteristics of a normal diesel engine powered with fossil diesel and also with the blends of diesel and microalgae methyl ester (B10, B20, \& B30) under variable load conditions and at a constant speed. The below conclusions were made with respect to the experimental data for B30 with the coated engine and pure diesel data with the base engine at full load condition,

1. The BSFC of $\mathrm{B} 30$ was reduced by $9.8 \%$, 
RASĀYAN J. Chem.

Vol. 14 | No. 3 |1972-1984| July - September | 2021

2. The BTE of B30 was increased by $13.53 \%$,

3. The EGT of B30 was marginally higher,

4. The $\mathrm{CO}$ emission of $\mathrm{B} 30$ was significantly decreased by $79.50 \%$,

5. The $\mathrm{CO}_{2}$ emission of $\mathrm{B} 30$ was enhanced by $5.42 \%$,

6. The $\mathrm{HC}$ emission of $\mathrm{B} 30$ was cut-off by $28.89 \%$,

7. The $\mathrm{NO}_{\mathrm{x}}$ emission of $\mathrm{B} 30$ was minimized by $17.65 \%$,

8. The Smoke Opacity of B30 was increased by $12.94 \%$,

9. The Ignition delay period of $\mathrm{B} 30$ was reduced by $4^{\circ} \mathrm{CA}$,

10. The In-Cylinder Pressure of B20 was increased by 3.72 bar and it was occurred between $5^{0}$ $8^{0} \mathrm{CA}$ after TDC,

11. The heat release rate was higher with $\mathrm{B} 30$, and it was occurred between $0^{0}-5^{\circ} \mathrm{CA}$ before TDC.

It could be claimed as per the above conclusions that the blend B30 (30\% MAME + 70\% Pure Diesel) has proven its potentiality to be used as a substitute for the fossil diesel fuel in a thermal barrier coated diesel engine, and it can further be stated that, this experiment may be extended to find out the characteristic features of a compression ignition engine with B30 doped by nanoparticles as a fuel using either normal piston or coated piston to obtain far better improvement in the characteristics of a conventional diesel engine.

\section{REFERENCES}

1. Tatikonda, N.C. and Naveenchandran, P., SAE Technical Paper, 2020-28-0441, 2020, https://doi.org/10.4271/2020-28-0441

2. Nambaya Charyulu, T., Naveenchandran, P., Raja, E. and R.N. Babu, Rasayan Journal of Chemistry, 13(2), 876(2020), https://doi.org/10.31788/RJC.2020.1325560

3. Sara Tayari, Reza Abedi, and Ali Abedi, Environmental and Climate Technologies, 24(1), 72(2020), https://doi.org/10.2478/rtuect-2020-0005

4. Selman Aydin, Cenk Sayin, Huseyn Aydin, and Rifat Yakut, SSRG International Journal of Thermal Engineering, 3(1), 12(2017)

5. M. Mohamed Musthafa, International Journal of Sustainable Engineering, (2017), https://doi.org/10.1080/19397038.2017.1393024

6. Ekrem Buyukkaya, Tahsin Engin, and Muhammet Cerit, Energy Conversion and Management, 47, 1298(2006), https://doi.org/10.1016/j.enconman.2005.06.021

7. Hanbey Hazar, Renewable Energy, (34), 1533(2009), https://doi.org/10.1016/j.renene.2008.11.008

8. M Ciniviz, C Hasimoglu, F. Sahin, and M S Salman, Journal of Automobile Engineering, 222(D), 2447(2008), https://doi.org/10.1243/09544070JAUTO851

9. M. Mohamedmusthafa, S.P. Sivapirakasam, M. Udayakumar, and K.R. Balasubramanian, Environmental Progress \& Sustainable Energy, 13(1), 147(2012), https://doi.org/10.1002/ep.10534

10. Huseyin Aydin, Applied Thermal Engineering, (51), 623(2013), https://doi.org/10.1016/j.applthermaleng.2012.10.030

11. M.J. Abedin, H.H. Masjuki, M.A. Kalam, A. Sanjid, and A.M. Ashraful, Energy Conversion and management, (85), 173(2014), https://doi.org/10.1016/j.enconman.2014.05.065

12. Bahattin Iscan, Journal of the Energy Institute, 1(2015), https://doi.org/10.1016/J.Joei.2015.01.001

13. Selman Aydin, Cenk Sayin, and Huseyin Aydin, Applied Thermal Engineering, (80), 212(2015), https://doi.org/10.1016/j.applthermaleng.2015.01.061

14. A. Vadivel, and S. Periyasamy, Journal of Applied Fluid Mechanics, 13(4), 1157(2020), https://doi.org/10.36884/jafm.13.04.30825

15. Vikrant Garuda, Sanjiwan Bhoite, Sagar Patil, Suraj Ghadage, Nilesh Gaikwad, Devesh Kute, and G. Sivakumar, In Proceedings of International Conference of Materials processing and Characterization, pp. 188-194, (2017)

16. M. Prabhahar, and K. Rajan, Journal of Mechanical Science and Technology, 27(5), 1519(2013), https://doi.org/10.1007/s12206-013-0332-3 
RASĀYAN J. Chem.

Vol. 14 | No. 3 |1972-1984| July - September | 2021

17. Chiranjeeva Rao Seela, Neelaiah Gade, and M. Srinivasa Rao, 2019, Analysis on CI Engine with Thermal Barrier Coating and Biodiesel Blends, Recent Advances in Material Sciences, Springer Nature, Singapore, pp.711-721, https://doi.org/10.1007/978-981-13-7643-6_58

18. V. Karthickeyanan, S. Thiyagarajan, B. Ashok, V. Edwin Geo, and A.K. Azad, Energy Conversion and Management, 205(2020), https://doi.org/10.1016/j.enconman.2019.112334

19. D. Das, G. Majumdar, R. S. Sen, and B. B. Ghosh, Journal of the Institution of Engineers (India),95(3), 63(2014), https://doi.org/10.1007/s40032-014-0104-6

20. V. Karthickeyan, Heat and Mass Transfer, (54), 1961(2018), https://doi.org/10.1007/s00231-0182286-6

21. V. Karthickeyan, P. Balamurugan, and R. Senthil, Biofuels, 207(2017), https://doi.org/10.1080/17597269.2017.1316142

22. Sivakumar Ellappan, and Bridjesh Pappula, Sustainable Environment Research, (29), 2(2019), https://doi.org/10.1186/s42834-019-0006-7

23. V. Karthickeyan, P. Balamurugan, and R. Senthil, The Brazilian Society of Mechanical Sciences and Engineering, (2016), https://doi.org/10.1007/s40430-016-0645-0

24. V. Karthickeyan, International Journal of Ambient Energy, 767(2017), https://doi.org/10.1080/01430750.2017.1341429

25. V. Karthickeyan, and P. Balamurugan, Heat and Mass Transfer, (53), 3141(2017), https://doi.org/10.1007/s00231-017-2058-8

26. S. Vedharaj, R. Vallinayagam, W.M. Yang, S.K. Chou, K.J.E. Chua, and P.S. Lee, Experimental Thermal and Fluid Science, (53), 259(2014), https://doi.org/10.1016/j.expthermflusci.2013.12.018

27. V. Karthickeyan, Australian Journal of Mechanical Engineering, 467(2018), https://doi.org/10.1080/14484846.2018.1546450

28. Selvam M, Shanmugan S, and Palani S, Environmental Science and Pollution Research, (25), 35210(2018), https://doi.org/10.1007/s11356-018-3419-7

29. S. Krishnamani, T. Mohanraj and K. Murugumohan Kumar, Indian Journal of Science and Technology, 9(15), (2016), https://doi.org/10.17485/ijst/2016/v9i15/87322

30. R. Senthil, E. Sivakumar, R. Silambarasan, and G. Pranesh, Biofuels, 235(2016), https://doi.org/10.1080/17597269.2016.1221299

31. D. Subramaniam, A. Murugesan, A. Avinash, and V. Arivadivan, International Journal of Ambient Energy, 35(1), 30(2014), https://doi.org/10.1080/01430750.2012.759152

32. Thiruselvam Krishnamoorthi1 and Ganesh Vinayagasundram, Environmental Science and Pollution Research, (26), 11438(2019), https://doi.org/10.1007/s11356-019-04637-w

33. R. T. Sarath Babu, M. Kannan and P. Lawrence, International Journal of ambient Energy, 844(2016), https://doi.org/10.1080/01430750.2016.1222963

34. Senthil Ramalingam, Silambarasan Rajendran and Pranesh Ganesan, Biofuels, 529(2016), https://doi.org/10.1080/17597269.2016.1168020

35. B. Dhinesh, Y. Maria Ambrose Raj, C. Kalaiselvan and R. Krishna Moorthy, Energy Conversion and Management, (171), 815(2018), https://doi.org/10.1016/j.enconman.2018.06.039

36. V.S. Shaisundaram, M. Chandrasekaran, S. Mohan Raj and R. Muraliraja, International Journal of Ambient Energy, 98(2018), https://doi.org/10.1080/01430750.2018.1451385

37. G. Siva Kumar, and S. Senthil Kumar, Alexandria Engineering Journal, 53(4), 787(2014), https://doi.org/10.1016/j.aej.2014.08.003

38. Ekrem Buyukkaya, and Muhammet Cerit, International Journal of Thermal Sciences, (47), 1096(2008), https://doi.org/10.1016/j.ijthermalsci.2007.07.009

39. B. Rajendra Prasath, P. Tamilporai, and Mohd. F. Shabir, International Journal of Thermal Sciences, (49), 2483(2010), https://doi.org/10.1016/j.ijthermalsci.2010.07.010

[RJC-6325/2020] 